Mr Boban Bondžulić,

kapetan, dipl. inž.

Vojna akademija,

Beograd

\section{ANALIZA REZULTATA DETEKCIJE POKRETA NA SLICI}

UDC: $004.4 ’ 275$

Rezime:

U radu je izvršeno poređenje pet metoda za određivanje praga detekcije pokreta na slici scene. Metodi su testirani na sintetičkim i realnim slikama, a rezultati detekcije pokreta izraženi su kvantitativno ili su dati vizuelno. Kvantitativna analiza izvršena je na nivou piksela, a zasnovana je na procentu ispravno klasifikovanih piksela, Jaccardovom i Yuleovom koeficijentu. Kroz analizu sprovedenu u četiri eksperimenta zaključeno je da su najbolji rezultati detekcije postignuti ukoliko se koristi Kapurov metod određivanja praga.

Ključne reči: detekcija pokreta, oduzimanje sukcesivnih frejmova, oduzimanje slike pozadine, metodi za određivanje praga detekcije pokreta, analiza rezultata detekcije pokreta.

\title{
PERFORMANCE EVALUATION OF CHANGE DETECTION
}

Summary:

This paper studies five different methods proposed for change detection thresholding. Methods were tested on synthetic and real pictures and results are quantitatively and qualitatively presented. Quantitative analysis is performed at pixel level and the following measures were used: the percentage of correct classification, the Jaccard coefficient and the Yule coefficient. We test the performance of thesholding methods in four experiments and Kapur was the best performing method both quantitatively and qualitatively.

Key words: change detection, successive frames subtraction, background subtraction, methods for change detection thresholding, performance evaluation of change detection.

\section{Uvod}

Za detekciju pokreta (promena) na slikama scene može se koristiti obrada slike razlike, koja se dobija oduzimanjem slike pozadine od tekućeg frejma ili oduzimanjem sukcesivnih frejmova. Ova detekcija praćena je uvođenjem praga da bi se dobila binarna slika u kojoj su pikseli klasifikovani u dve klase (pozadina i pokretni objekat).

Jedan metod određivanja praga detekcije pokreta neće biti dobar za sve primene. Takođe, različiti metodi nisu podjednako korisni za konkretnu primenu.
Zbog toga je procena rezultata detekcije bitna, kako za odabir odgovarajuće metode, tako i za optimalan izbor parametara koji su potrebni za pojedine metode određivanja praga detekcije. Odabir metrike procene je veoma težak zadatak i ne postoji standardna metrika za objektivnu procenu rezultata detekcije.

U ovom radu izvršeno je poređenje pet metoda za određivanje praga detekcije pokreta na slici scene. Jedan od metoda predložio je autor, a ostala četiri preuzeta su iz literature. Metodi su ispitani na sintetičkim slikama i na slikama realne scene. Slike scene formirane su nepo- 
kretnom televizijskom i termovizijskom kamerom.

\section{Detekcija pokreta oduzimanjem sukcesivnih frejmova}

Ako je $\mathrm{I}^{\mathrm{n}}(\mathrm{x}, \mathrm{y})$ vrednost nivoa sivog piksela frejma (slike) na poziciji $(\mathrm{x}, \mathrm{y}) \mathrm{u}$ trenutku $t=t_{n}$, mera sličnosti dva frejma, uzeta $u$ trenutku $t=t_{n} i t=t_{n-1}$, može se izraziti kao:

$$
\begin{aligned}
& D^{n}(x, y)=\left|I^{n}(x, y)-I^{n-1}(x, y)\right|, \\
& \forall(x, y) \in[1, N] \times[1, M]
\end{aligned}
$$

gde je NxM dimenzija frejma u pikselima i gde intenzitet piksela frejma može uzeti bilo koju vrednost iz skupa [0, 1, 2,.., 255]. $\mathrm{Na}$ taj način dobija se slika razlike $\mathrm{D}^{\mathrm{n}}$.

\section{Detekcija pokreta oduzimanjem slike pozadine od tekućeg frejma}

Sa $B^{n}(x, y)$ označen je intenzitet piksela slike pozadine na poziciji $(\mathrm{x}, \mathrm{y})$, $\mathrm{u}$ trenutku $\mathrm{t}=\mathrm{t}_{\mathrm{n}}$. Uz pretpostavku da je slika pozadine poznata, detekcija pokreta može se izvršiti na osnovu razlike tekućeg frejma i slike pozadine:

$$
\begin{aligned}
& D^{n}(x, y)=\left|I^{n}(x, y)-B^{n}(x, y)\right|, \\
& \forall(x, y) \in[1, N] \times[1, M]
\end{aligned}
$$

Da bi se eliminisao uticaj šuma i donela odluka o tome kod kojih piksela je došlo do promene nivoa sivog zbog prisustva pokretnih objekata, potrebno je na sliku razlike $\mathrm{D}^{\mathrm{n}}(\mathrm{x}, \mathrm{y})$ primeniti prag $\mathrm{T}$
$(T \in[0,255])$. Na taj način dobija se binarna slika $\mathrm{I}_{\mathrm{b}}^{\mathrm{n}}(\mathrm{x}, \mathrm{y})$, u kojoj su pikseli klasifikovani u dve klase (pozadina i pokretni piksel), tj:

$$
I_{b}^{n}(x, y)=\left\{\begin{array}{c}
0, D^{n}(x, y) \leq T \\
255, D^{n}(x, y)>T
\end{array}\right.
$$

\section{Metodi za određivanje praga detekcije pokreta}

U radu su analizirani Otsuov, Tsaijev, Kapurov, Rosinov metod i metod koji je predložio autor.

Otsu je u radu [1] predložio metod za analitičko određivanje vrednosti praga koji je zasnovan na diskriminantnoj analizi. Ovaj metod obezbeđuje maksimalnu separabilnost regiona, koji predstavljaju objekat i pozadinu, a za određivanje praga koristi histogram slike.

Određivanje praga pomoću očuvanja momenata predložio je Tsai [2]. Pre određivanja praga računaju se momenti nivoa sivog ulazne slike. Prag se, zatim, određuje tako da momenti izlazne slike, koja se dobija primenom praga na ulaznu sliku, budu isti kao momenti ulazne slike.

Kapur [3] je koristio Shannonovu definiciju entropije. Međutim, umesto da posmatra jednu gustinu verovatnoće nivoa sivog čitave slike, on je posmatrao dve gustine verovatnoće, jednu za pozadinu i drugu za objekat.

Rosin je za određivanje praga detekcije pokreta koristio Eulerov broj [4], koji predstavlja meru topologije binarne slike.

Predloženi način određivanja praga detekcije pokreta autora zasnovan je na blokovskoj podeli slike razlike i verovat- 
noći lažnog alarma [5]. Prag detekcije je u [5] izveden za Gausovu i Laplasovu raspodelu nivoa sivog na slici razlike. Osnovni problem koji se javlja pri određivanju praga detekcije pokreta je estimacija standardne devijacije šuma u slici. Problem je rešen podelom slike razlike na blokove $8 \times 8$ piksela i usrednjavanjem određenog broja najmanjih standardnih devijacija blokova.

\section{Mere detekcije pokreta}

Standardna metrika za procenu rezultata detekcije ne postoji jer se u obradi slike koristi kvalitativna definicija dobre segmentacije (klasifikacije) [6] po kojoj regioni dobijeni postupkom segmentacije treba da budu uniformni i homogeni $u$ odnosu na neke karakteristike, kao što su nivo sivog ili tekstura. Unutrašnjost regiona treba da bude jednostavna i bez malih rupa, a granice regiona jednostavne, glatke i prostorno tačne. Susedni regioni treba da budu dovoljno različiti po onom atributu po kojem su uniformni. Detekcija promena predstavlja jednu vrstu segmentacije.

Uobičajena praksa za procenu rezultata detekcije pokreta bazira se na proceni rezultata određenog broja posmatrača (subjektivna procena). Da bi se dobili statistički relevantni rezultati potreban je znatan broj posmatrača (reprezentativan uzorak), čineći subjektivnu procenu vremenski dugom i veoma skupom [7].

Da bi se izbegla subjektivna procena, potrebna je procedura za automatsku procenu rezultata detekcije. Procedura automatske procene naziva se objektivna procena. Metrika za objektivnu procenu može se primeniti na metod određivanja praga detekcije (analitički metodi) ili na rezultate detekcije (empirijski metodi).

Analitički metodi procenjuju postupak određivanja praga na osnovu principa određivanja praga, specifičnosti metoda, njegove kompleksnosti i sl. Prednost ovih metoda jeste što se procena vrši bez implementacije samog algoritma. Međutim, kako teorija detekcije pokreta nije u potpunosti razvijena, kao i zbog toga što algoritam detekcije pokreta može biti kompleksan, sastavljen od nekoliko celina, algoritam detekcije se veoma teško može proceniti na ovakav način [7].

Kod empirijskih metoda za izbor postupka određivanja praga, prag se primenjuje na skup test slika koje su relevantne za konkretnu primenu. Algoritam koji daje najbolje rezultate zatim se koristi u konkretnoj aplikaciji. Empirijski metodi često se nazivaju i metodi neslaganja, jer se rezultati detekcije porede sa referentnom detekcijom. Referentna ili idealna detekcija može se dobiti ručno ili pomoću pouzdane procedure.

Procena je zasnovana na parametrima neslaganja, koji mogu biti zasnovani na prostornom i vremenskom odstupanju. Na primer, pikseli koji su pogrešno klasifikovani dele se u dve grupe - na one koji pripadaju rezultatu detekcije ali ne i idealnoj detekciji-klasifikaciji (false positive) i one koji pripadaju idealnoj detekciji ali ne i rezultatu detekcije (false negative) $[7,8]$. Osim toga, vremenska nepromenljivost (stabilnost) detektovanih objekata može se razmatrati. Parametri neslaganja prostorne procene mogu biti vernost oblika, geometrijska sličnost, ivice, sličnost statistika i sl. Vremenska 
stabilnost i prostorna procena mogu se kombinovati i zajedno posmatrati.

U primenama gde se kao krajnji korisnik javlja čovek bitno je da se uzme u obzir i vizuelni sistem čoveka za procenu kvaliteta detekcije. Metodi procene uglavnom ne uzimaju ovaj aspekt i razmatraju samo objektivne kriterijume, kao što je odstupanje u odnosu na idealnu detekciju.

Test slike za procenu metoda određivanja praga mogu biti sintetičke, pseudosintetičke ili slike realnih scena.

\section{Metodologija procene rezultata detekcije}

Performanse metoda određivanja praga detekcije pokreta biće izražene kvantitativno, poredeći rezultat detekcije metoda i rezultat idealne detekcije, a $u$ situacijama kada se ne raspolaže rezultatima idealne detekcije rezultati će biti prikazani vizuelno.

Kako je cilj procene poređenje na velikom broju test-slika, rezultat idealne detekcije generiše se automatski, jer je bilo koji drugi način spor i naporan. Zbog toga su rezultati nekih realnih test-slika prikazani vizuelno. Test-slike koje se koriste su sintetičke i realne, a njihov nedostatak jeste što se svi procesi koji se javljaju na sceni ne mogu modelovati: uticaj senke, promene vremenskih uslova, itd.

Nakon generisanja sintetičkih test-slika moguće je dobiti sekundarni skup slika, na primer, dodavanjem šuma, promenom kontrasta, simulacijom susreta objekata i sl. Takođe, stvarni objekat može se izdvojiti iz realne sekvence i veštački ubaciti u novu video sekvencu. Iako slike dobijene na ovakav način nisu potpuno realne, one se mogu koristiti za testiranje metoda.
Postoji više načina za analizu performansi metoda određivanja praga, počev od analize na najnižem nivou - analize na nivou piksela, pa do analize na višim nivoima. Analiza na višim nivoima uzima u obzir mogućnost primene metoda u konkretnoj aplikaciji. Performanse metoda određivanja praga biće posmatrane na nivou piksela.

Rezultat analize na najnižem nivou, koji je zasnovan na poređenju rezultata detekcije i idealne detekcije, zasniva se na sledećim veličinama:

- broj piksela promena koji su ispravno klasifikovani - true positives (TP);

- broj nepokretnih piksela (pikseli pozadine) koji su nepravilno klasifikovani - false positives (FP);

- broj nepokretnih piksela koji su pravilno klasifikovani - true negatives (TN);

- broj piksela promena koji su nepravilno klasifikovani - false negatives $(\mathrm{FN})$.

Od ove četiri veličine formirane su sledeće mere sličnosti [9]:

- procenat ispravno klasifikovanih piksela (percentage correct classification):

$$
\begin{aligned}
& P C C=\frac{T P+T N}{T P+F P+T N+F N} \\
& - \text { Jaccardov koeficijent: } \\
& \frac{T P}{T P+F P+F N}
\end{aligned}
$$

- Yuleov koeficijent:

$$
\left|\frac{T P}{T P+F P}+\frac{T N}{T N+F N}-1\right|
$$


Za procenu rezultata detekcije najčešće se koristi mera PCC. Međutim, ova mera može dati pogrešnu procenu kada je broj pokretnih piksela mali u odnosu na broj piksela čitave slike. Tako, ako je broj piksela promena npr. 4\%, veliki koeficijent PCC (96\%) dobija se ako se kompletna slika proglasi pozadinom. Yuleov i Jaccardov koeficijent prevazilaze ovaj problem na taj način što minimiziraju uticaj velikog broja TN. Treba primetiti i da se Yuleov koeficijent ne može koristiti u situacijama kada je jedan od imenilaca jednak nuli.

\section{Opis i analiza rezultata prvog eksperimenta}

U prvom eksperimentu analizirana je situacija kada na sceni nije bilo pokretnih objekata. Koristile su se sintetičke slike i slike realne scene. Za procenu rezultata koristio se samo koeficijent PCC, jer na sceni nema pokretnih objekata.

Sintetičke slike su dimenzija $512 \times$ 12 piksela. Inicijalna pozadina je uni- formna, a njen nivo sivog je 127 (srednji nivo na skali od 0 do 255 nivoa sivog). Zatim je inicijalnoj pozadini dodavan Gausov šum nulte srednje vrednosti, a standardne devijacije $\sigma_{\mathrm{n}}$, čija je vrednost menjana od 1 do 30 nivoa sivog. Slike razlike dobijene su oduzimanjem sukcesivnih frejmova.

Usvojena verovatnoća lažnog alarma za metod autora, za Gausovu (M1 u daljoj analizi) i Laplasovu (M2 u daljoj analizi) raspodelu, iznosi $\mathrm{Pla}=10^{-1}$.

Na sl. 1 prikazane su inicijalna slika pozadine (sl. 1a) i vrednosti koeficijenata PCC za pet analiziranih metoda (sl. 1b). Vrednost koeficijenta PCC data je u funkciji standardne devijacije šuma (sl. 1a).

Sa sl. $1 b$ vidi se da najbolje rezultate detekcije daju pragovi koji se određuju Rosinovim i Kapurovim metodom. Lošiji rezultati dobijaju se ukoliko se koriste pragovi koji se određuju Tsaijevim i Otsuovim metodom. Rezultati metoda autora nalaze se između rezultata koje daju navedeni metodi. Takođe, vidi se da se u slučaju predloženog metoda vrednost koefi-

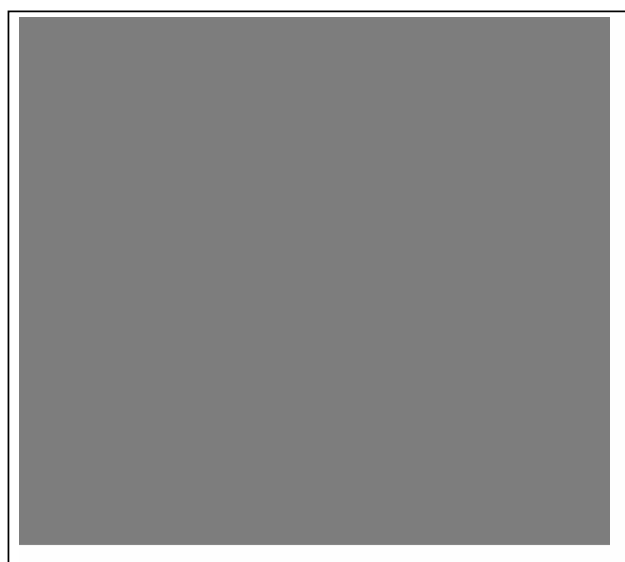

(a)

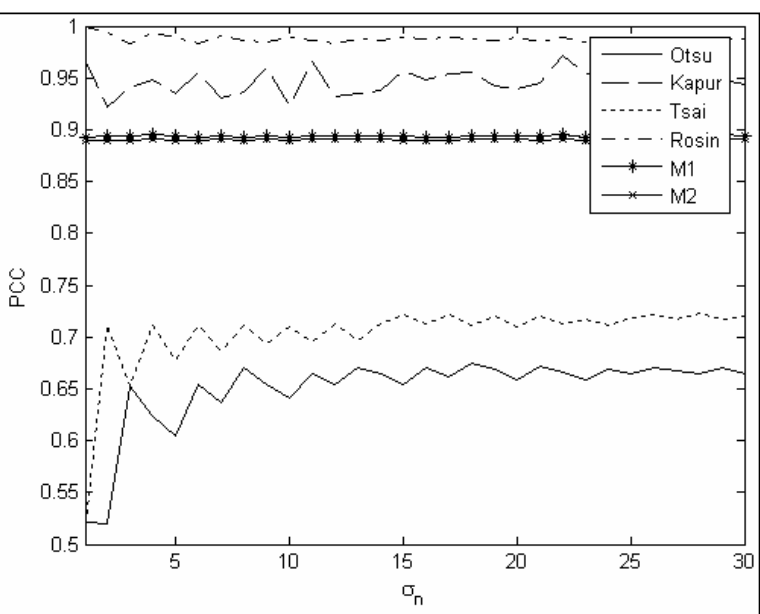

(b)

Sl. 1 - (a) inicijalna pozadina, (b) vrednosti koeficijenata PCC za različite vrednosti $\sigma_{n}$ 
Opis situacija i broj korišćenih frejmova

\begin{tabular}{|l|l|c|}
\hline & \multicolumn{1}{|c|}{ OPIS SITUACIJE } & BROJ FREJMOVA \\
\hline Situacija 1 & U prostoriji upaljeno svetlo & 48 \\
\hline Situacija 2 & U prostoriji prisutna dnevna svetlost & 43 \\
\hline Situacija 3 & Postavljen zastor na jedan od prozora & 33 \\
\hline Situacija 4 & Postavljen zastor na oba prozora & 48 \\
\hline Situacija 5 & Postavljen dupli zastor na jedan od prozora & 33 \\
\hline Situacija 6 & Postavljen dupli zastor na oba prozora & 39 \\
\hline
\end{tabular}

cijenta PCC kreće oko vrednosti 0,89 , što govori o tome da je algoritam dobro implementiran (verovatnoća lažnog alarma je Pla $=10^{-1}$, a nema pokreta na sceni).

$\mathrm{Za}$ analizu realnih scena sproveden je eksperiment $u$ toku kojeg je snimana ista scena šest puta, uz promenu osvetljenosti scene. Eksperiment je sproveden $\mathrm{u}$
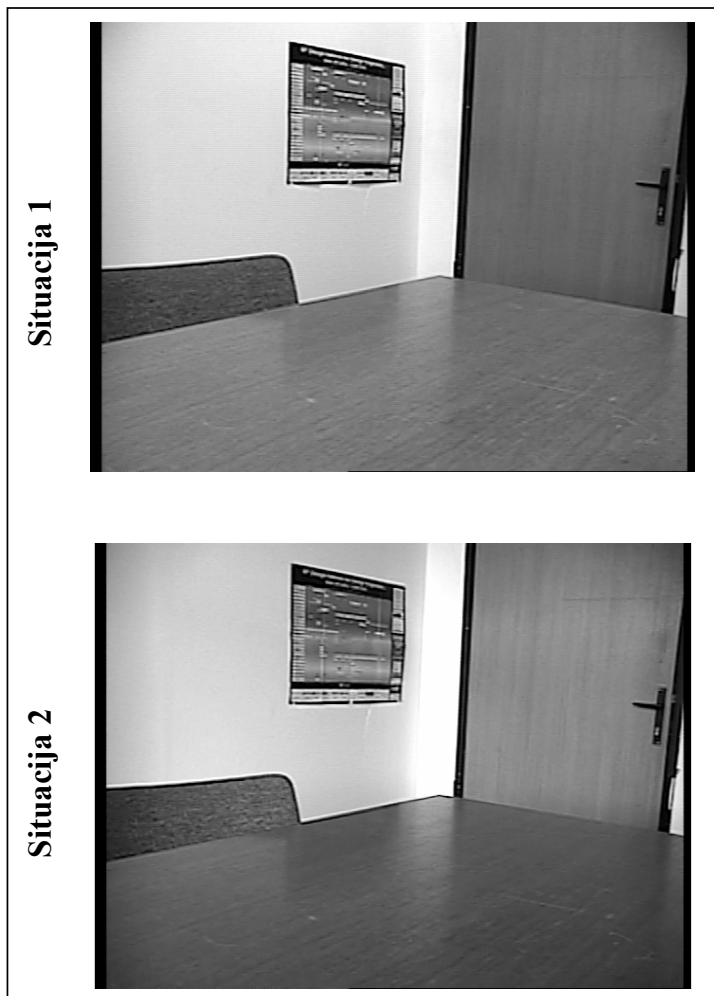

(a) zatvorenoj prostoriji dana 26. 12. 2004. godine, od 10.54 do $11.29 \mathrm{~h}$. U tabeli 1 opisane su situacije u kojima je scena snimana i broj frejmova koji se koristio $\mathrm{u}$ analizi. Slike scene dobijene su pomoću televizijske kamere firme Samsung, tip SCL860, u vidljivom delu spektra $(0,4-0,7) \mu \mathrm{m}$.
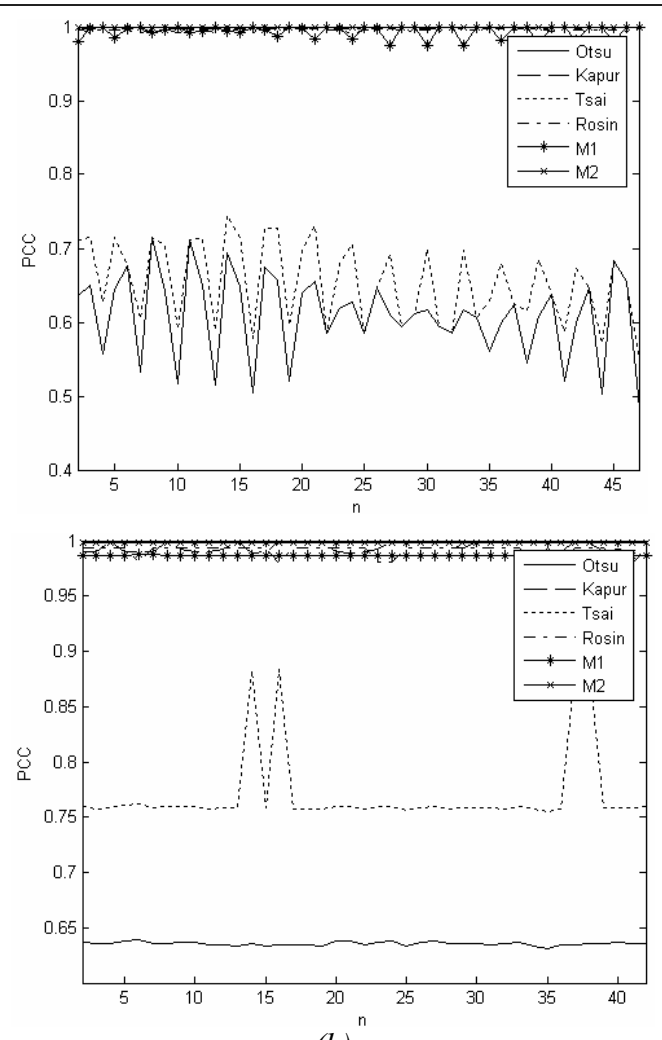

(b)

Sl. 2 - (a) prvi frejmovi analiziranih sekvenci, (b) vrednosti koeficijenata PCC 
Na sl. 2 prikazani su prvi frejmovi sekvenci koji odgovaraju situacijama 1 i 2 (sl. 2a) i vrednosti koeficijenata PCC koji se dobijaju u navedenim situacijama (sl. 2b).

Sa sl. $2 b$ vidi se, da se i u slučaju realne scene, lošiji rezultati dobijaju ukoliko se koriste pragovi dobijeni Tsaijevim i Otsuovim metodom. Rezultati metoda autora su u skladu sa rezultatima koji se dobijaju kada se koriste pragovi dobijeni Rosinovim i Kapurovim metodom. Bolji rezultati metoda autora u odnosu na slučaj kada su se koristile sintetičke slike dobijeni su, jer je verovatnoća lažnog alarma $\mathrm{Pla}=10^{-4}$. Slični rezultati dobijaju se kada se analiziraju sekvence slika koje odgovaraju ostalim situacijama.

\section{Opis i analiza rezultata drugog eksperimenta}

U drugom eksperimentu analizirana je situacija kada je na sceni postojao jedan pokretni objekat, a u eksperimentu su korišćene slike realne scene. Slike scene dobijene su pomoću televizijske kamere firme Samsung, tip SCL860, u vidljivom delu spektra $(0,4-0,7) \mu \mathrm{m}$, a slike su snimljene u uslovima koji su opisani u tabeli 1 . Kao pokretni objekti korišćene su knjige: prva (označena kao $\mathrm{K} 1$ ), čiji se nivoi sivog razlikuju od pozadine, i druga (označena kao K2), čiji nivoi sivog su slični pozadini.

Kako je u slučaju korišćenja realnih slika scene veoma teško odrediti rezultat idealne detekcije, u ovom slučaju biće prikazane binarne slike koje se dobijaju primenom pragova različitih metoda na slike razlike. Slike razlike formirane su oduzimanjem slike pozadine i oduzimanjem sukcesivnih frejmova.

Za metod autora usvojena verovatnoća lažnog alarma za Gausovu i Laplasovu raspodelu je $\mathrm{Pla}=10^{-4}$.

Analiza je sprovedena za oba pokretna objekta i za svih šest situacija, a u radu su dati rezultati dobijeni za pokretne objekte u prostoriji sa zastorom na jednom prozoru (situacija 3 ).

Na sl. 3 i 4 prikazane su slika pozadine, slučajno odabrani frejmovi analiziranih sekvenci koje odgovaraju situaciji 3 i rezultati detekcije pokreta. Slike razlike formirane su oduzimanjem slike pozadine od tekućeg frejma.

Ista analiza sprovedena je i za oduzimanje sukcesivnih frejmova. $\mathrm{Kroz}$ kompletnu analizu utvrđeno je da su pokretni objekti detektovani u velikom opsegu promene osvetljenosti (situacije 1-5), nezavisno od izbora metoda određivanja praga detekcije.

Kroz šest analiziranih situacija zaključeno je da je najbolje rezultate detekcije dao Kapurov metod određivanja praga detekcije (vizuelna procena posmatrača). Ovaj način određivanja praga pokazao se kao najotporniji na uticaj šuma i na uticaj senke.

U tabelama 2 i 3 prikazane su vrednosti pragova koje odgovaraju analiziranim situacijama. U tabeli 2 to su vrednosti pragova dobijene u slučaju oduzimanja slike pozadine od tekućeg frejma, a u tabeli 3 vrednosti pragova dobijene u slučaju oduzimanja sukcesivnih frejmova. Maksimalne i minimalne vrednosti pragova u tabelama 2 i 3 obeležene su tamnosivom i svetlosivom bojom. 




Iz tabela 2 i 3 vidi se da za sve metode određivanja praga, vrednost praga zavisi od osvetljenosti scene. Za metode koji su preuzeti iz literature (Otsu, Tsai, Kapur i Rosin) vrednosti praga zavise i od pokretnog objekta, o kojem se radi

(K1 odnosno K2). Ako se za ove metode uporede vrednosti praga dobijene u slučaju oduzimanja slike pozadine i oduzimanja sukcesivnih frejmova, može se zaključiti da vrednosti praga zavise i od broja pokretnih piksela. 


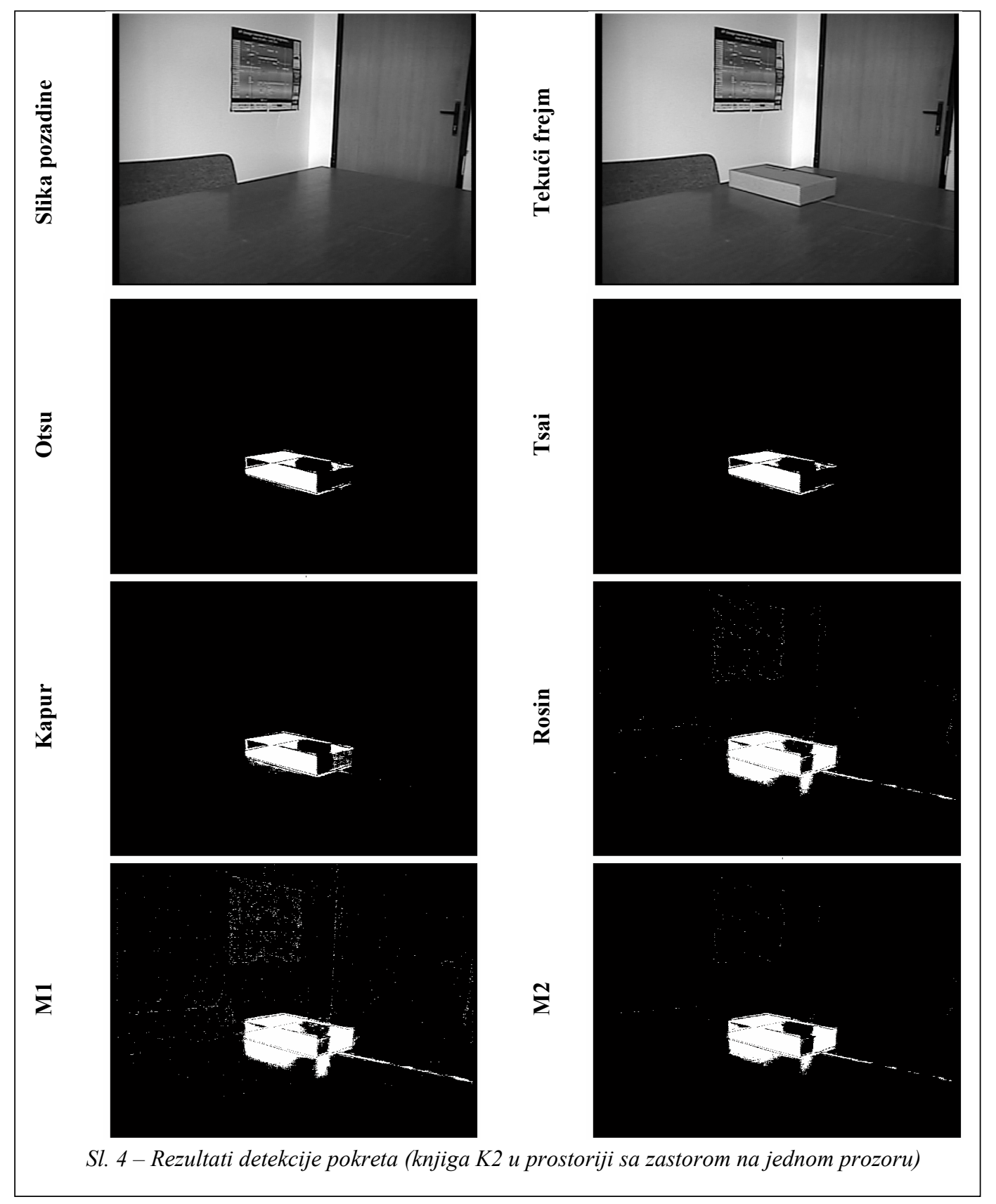

Ukoliko se koristi metod određivanja praga autora, vrednost praga skoro da i ne zavisi od broja pokretnih piksela, kao ni od toga o kom pokretnom objektu se radi. Izuzetak su situacije 1 (K2) i 2 (K1) zbog malog pokreta kamere $\mathrm{u}$ toku snimanja. To se moglo i očekivati polazeći od toga da vrednost praga ovog metoda zavisi od željene verovatnoće lažnog alarma i standardne devijacije šuma slike razlike. 
Vrednosti pragova analiziranih metoda u slučaju oduzimanja slike pozadine od tekućeg frejma

\begin{tabular}{|c|c|c|c|c|c|c|c|c|c|c|c|c|}
\hline & \multicolumn{2}{|c|}{ SITUACIJA 1} & \multicolumn{2}{|c|}{ SITUACIJA 2} & \multicolumn{2}{|c|}{ SITUACIJA 3} & \multicolumn{2}{|c|}{ SITUACIJA 4} & \multicolumn{2}{|c|}{ SITUACIJA 5} & \multicolumn{2}{|c|}{ SITUACIJA 6} \\
\hline & K1 & $\mathrm{K} 2$ & K1 & $\mathrm{K} 2$ & $\mathrm{~K} 1$ & K2 & $\mathrm{K} 1$ & $\mathrm{~K} 2$ & $\mathrm{~K} 1$ & $\mathrm{~K} 2$ & $\mathrm{~K} 1$ & $\mathrm{~K} 2$ \\
\hline Otsu & 69 & 69 & 64 & 58 & 46 & 40 & 30 & 25 & 9 & 7 & 5 & 5 \\
\hline Tsai & 83 & 82 & 82 & 48 & 49 & 43 & 27 & 15 & 13 & 9 & 6 & 6 \\
\hline Kapur & 71 & 93 & 52 & 23 & 30 & 30 & 19 & 19 & 35 & 19 & 24 & 15 \\
\hline Rosin & 33 & 33 & 20 & 15 & 13 & 13 & 18 & 15 & 28 & 20 & 15 & 15 \\
\hline M1 & 28 & 18 & 14 & 10 & 9 & 9 & 17 & 17 & 23 & 23 & 17 & 17 \\
\hline M2 & 47 & 31 & 23 & 17 & 16 & 15 & 29 & 29 & 38 & 38 & 29 & 30 \\
\hline
\end{tabular}

Vrednosti pragova analiziranih metoda u slučaju oduzimanja sukcesivnih frejmova

Tabela 3

\begin{tabular}{|c|c|c|c|c|c|c|c|c|c|c|c|c|}
\hline & \multicolumn{2}{|c|}{ SITUACIJA 1} & \multicolumn{2}{|c|}{ SITUACIJA 2} & \multicolumn{2}{|c|}{$\begin{array}{l}\text { SITUACIJA } 3 \\
\end{array}$} & \multicolumn{2}{|c|}{ SITUACIJA 4} & \multicolumn{2}{|c|}{ SITUACIJA 5} & \multicolumn{2}{|c|}{ SITUACIJA 6} \\
\hline & $\mathrm{K} 1$ & $\mathrm{~K} 2$ & $\mathrm{~K} 1$ & $\mathrm{~K} 2$ & $\overline{\mathrm{K} 1}$ & $\mathrm{~K} 2$ & $\mathrm{~K} 1$ & $\mathrm{~K} 2$ & $\mathrm{~K} 1$ & $\mathrm{~K} 2$ & $\mathrm{~K} 1$ & $\mathrm{~K} 2$ \\
\hline Otsu & 68 & 37 & 61 & 54 & 62 & 32 & 43 & 26 & 7 & 6 & 5 & 5 \\
\hline Tsai & 45 & 29 & 73 & 43 & 64 & 39 & 37 & 16 & 13 & 9 & 6 & $\overline{6}$ \\
\hline Kapur & 34 & 54 & 26 & 43 & 29 & 83 & 23 & 20 & 25 & 21 & 25 & 15 \\
\hline Rosin & 25 & 20 & 15 & 12 & 12 & 12 & 17 & 15 & 20 & 20 & 15 & 15 \\
\hline M1 & 30 & 13 & 10 & 9 & 9 & 9 & 17 & 16 & 22 & 22 & 17 & 17 \\
\hline M2 & 51 & 22 & 16 & 16 & 15 & 15 & 28 & 28 & 38 & 37 & 29 & 29 \\
\hline
\end{tabular}

\section{Opis i analiza rezultata trećeg eksperimenta}

U trećem eksperimentu analizirana je situacija kada je na sceni postojao jedan pokretni objekat, a u eksperimentu su korišćene sintetičke slike. Za potrebe sprovođenja eksperimenta formirana je sekvenca Kraj.avi od 450 frejmova. Dimenzije frejmova u sekvenci su $512 \times 512$ piksela. Po-

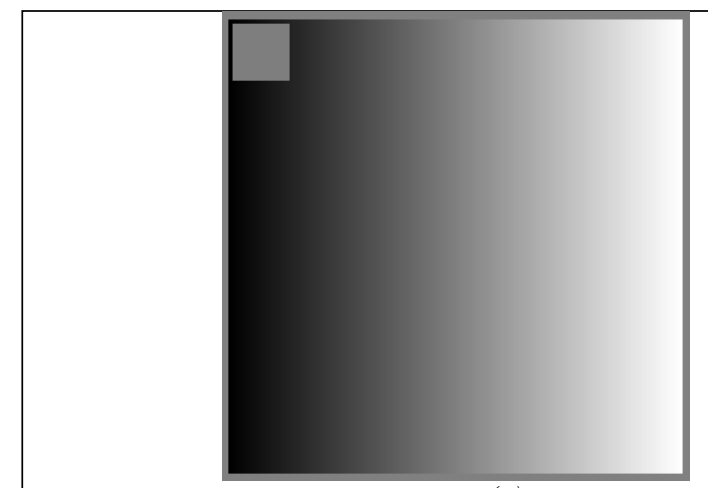

(a) zadina sekvence formirana je tako što se nivo sivog menjao sleva udesno, od minimalnog do maksimalnog. Nivo sivog piksela jedne kolone je isti. Zatim je pozadini dodat objekat koji ima nivo sivog 127 (srednji nivo na skali od 0 do 255). Dimenzije objekta su $64 \times 64$ piksela, a njegova početna pozicija je u gornjem levom uglu. Ovaj objekat zatim je pomeran dijagonalno, ka donjem desnom uglu.

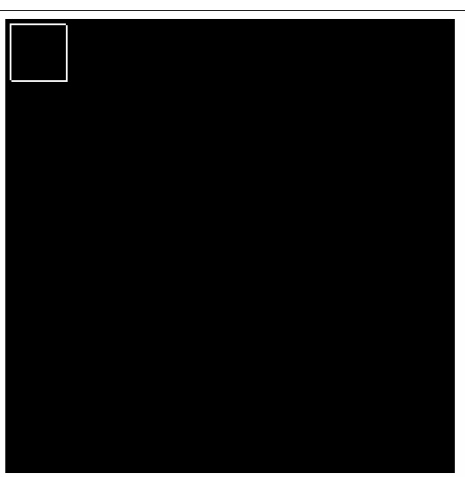

(b)

Sl. 5 - (a) treći frejm sekvence Kraj.avi, (b) rezultat idealne detekcije 
$\mathrm{Za}$ potrebe analize, frejmovima sekvence dodavan je Gausov šum nulte srednje vrednosti, a standardne devijacije $\sigma_{n}$ čija je vrednost menjana od 1 do 20 nivoa sivog. Slike razlike formirane su oduzimanjem sukcesivnih frejmova. Kako se $\mathrm{u}$ ovom slučaju raspolaže sa rezultatima idealne detekcije, određene su vrednosti koeficijenta PCC, Yuleovog i Jaccardovog koeficijenta. Za metod autora usvojena verovatnoća lažnog alarma za Gausovu i Laplasovu raspodelu je $\mathrm{Pla}=10^{-4}$.

$\mathrm{Na}$ sl. 5 prikazani su treći frejm sekvence Kraj.avi i rezultat idealne detekcije.

Na sl. 6 prikazane su vrednosti analiziranih koeficijenata za različite vred- nosti $\sigma_{n}$. Vrednosti koeficijenata dobijene su usrednjavanjem, tj. za istu vrednost $\sigma_{n}$ koeficijenti su određeni za sve pomeraje objekta, a zatim usrednjeni.

Sa sl. 6a vidi se da najbolje rezultate daju pragovi određeni Kapurovim, Rosinovim i pragovi po metodu autora (M1 i M2). U pogledu Jaccardovog i Yuleovog koeficijenta izdvajaju se pragovi određeni Kapurovim metodom i predloženim metodom uz pretpostavku o Gausovoj (M1) raspodeli šuma na slici razlike. Veće vrednosti Jaccardovog i Yuleovog koeficijenta govore o boljim performansama metoda. U sva tri slučaja najlošiji rezultati postižu se primenom pragova dobijenih po metodima koji su

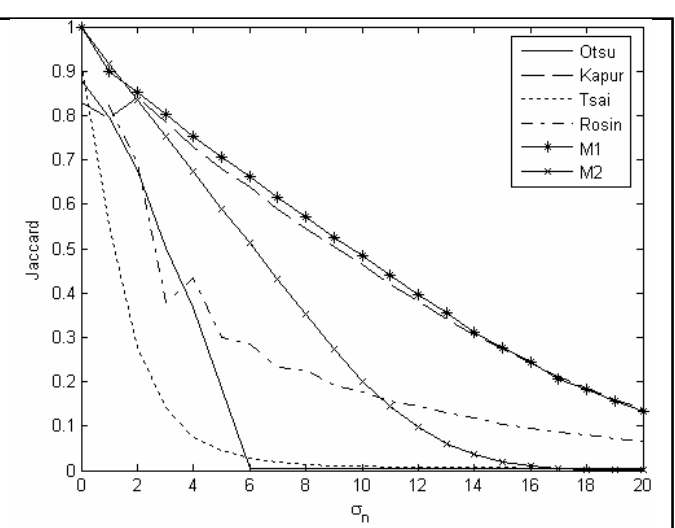

(b)

(a)

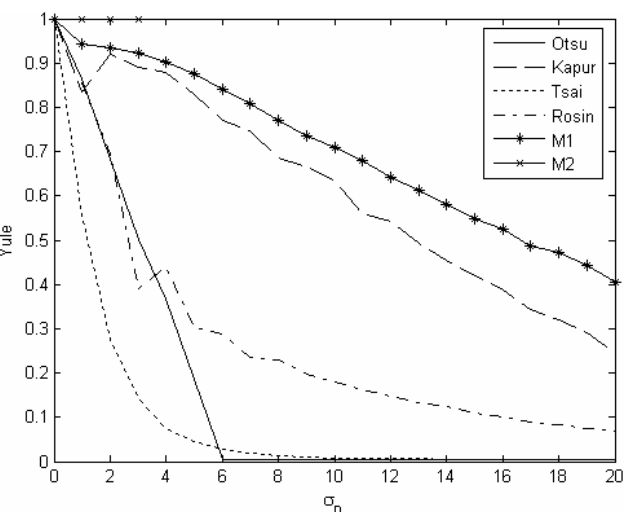

(v)

Sl. 6 - (a) vrednosti koeficijenta PCC, (b) vrednosti Jaccard-ovog koeficijenta, (v) vrednosti Yule-ovog koeficijenta 
predložili Otsu i Tsai. Sa sl. 6v može se primetiti da ukoliko se koristi predloženi metod i pretpostavka o Laplasovoj raspodeli nivoa sivog šuma, vrednosti Yuleovog koeficijenta postoje, samo za vrednosti $\sigma_{n}$ od jedan do tri. Za veće vrednosti standardne devijacije $\sigma_{n}$, vrednosti ovog koeficijenta ne postoje, jer je jedan od imenilaca u izrazu za vrednost Yuleovog koeficijenta jednak nuli.

\section{Opis i analiza rezultata četvrtog eksperimenta}

U četvrtom eksperimentu analizirana je situacija kada su na sceni postojali pokretni objekti. U eksperimentu su korišćene termovizijske i televizijske slike iste scene. Slike scene dobijene su pomoću televizijske kamere firme Samsung, tip SCL860, u vidljivom delu spektra $(0,4-0,7) \mu \mathrm{m}$ i termovizijske kamere firme ATIS (Advanced Thermal Imaging System), u dalekom infracrvenom delu spektra (8-12) $\mu \mathrm{m}$. Formirane su baze od po jedanaest sekvenci televizijskih i termovizijskih slika dve scene, bliske scene na daljini oko $70 \mathrm{~m}$ i daleke scene na daljini oko $4 \mathrm{~km}$. Baza slika formirana je fiksnim kamerama postavljenim na platformu zgrade u VTI-ju, 19. 11. 2004. od 10.30 do $11.50 \mathrm{~h}$.

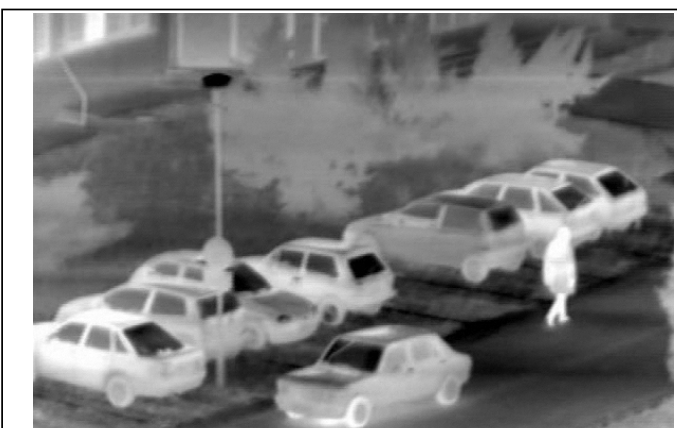

(a) termovizijska slika bliske scene
Na sl. 7 prikazani su frejmovi termovizijske i televizijske sekvence bliske scene. Vidljivi su detalji na obe slike, iako je termovizijska slika formirana sa širokim vidnim poljem. Pri formiranju baze slika vidno polje televizijske kamere podešavano je prema vidnom polju termovizijske kamere. Na termovizijskim slikama objekti sa većom emisijom (topli delovi objekata) prikazani su u svetlijoj nijansi sivog.

Kako je u slučaju korišćenja realnih slika scene veoma teško odrediti rezultat idealne detekcije, u ovom slučaju biće prikazane binarne slike koje se dobijaju primenom pragova različitih metoda na slike razlike dobijene oduzimanjem sukcesivnih frejmova.

Binarne slike koje se dobijaju primenom pragova različitih metoda na slike razlike koje odgovaraju slikama na sl. 7, prikazane su na sl. 8 .

Na slikama bliske scene mogu se videti konture putničkog automobila i čoveka u pokretu. Na sl. 8a, koja odgovara rezultatu koji se dobija po metodu autora (M1 i M2), detektovane su linije piksela koje potiču od toplog traga automobila $u$ pokretu. Za metod autora usvojena je verovatnoća lažnog alarma $\mathrm{Pla}=10^{-4}$.

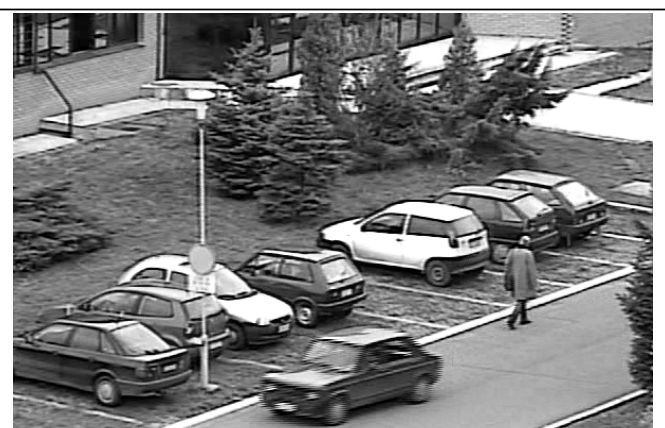

(b) televizijska slika bliske scene

Sl. 7 - Termovizijska i televizijska slika bliske scene 


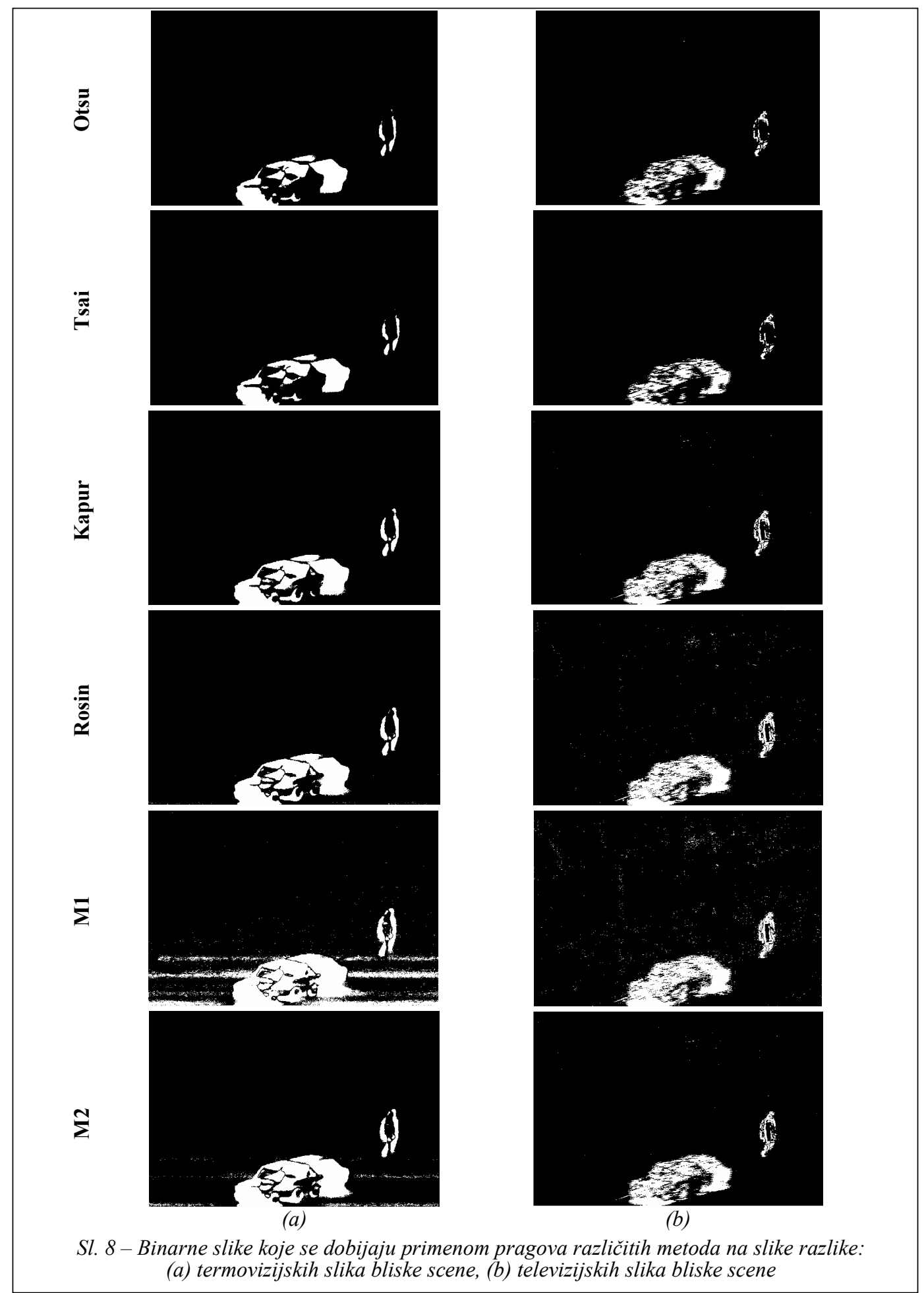


Vrednosti pragova dobijene po analiziranim metodima, za termovizijske

$i$ televizijske slike bliske $i$ daleke scene

\begin{tabular}{|l|c|c|c|c|}
\hline & \multicolumn{2}{|c|}{ BLISKA SCENA } & \multicolumn{2}{c|}{ DALEKA SCENA } \\
\hline & Termovizijska slika & Televizijska slika & Termovizijska slika & Televizijska slika \\
\hline Otsu & 60 & 62 & $\mathbf{3 9}$ & $\mathbf{3 6}$ \\
\hline Tsai & $\mathbf{6 4}$ & $\mathbf{7 1}$ & $\mathbf{1 7}$ & 19 \\
\hline Kapur & 36 & 36 & 25 & 13 \\
\hline Rosin & 28 & 25 & 20 & $\mathbf{1 2}$ \\
\hline M1 & $\mathbf{1 4}$ & $\mathbf{2 0}$ & $\mathbf{1 7}$ & 20 \\
\hline M2 & 23 & 34 & 28 & \\
\hline
\end{tabular}

U tabeli 4 prikazane su vrednosti pragova dobijene po analiziranim metodima, za termovizijske i televizijske slike bliske i daleke scene. Maksimalne i minimalne vrednosti pragova u tabeli 4 obeležene su tamnosivom i svetlosivom bojom.

Ako se za predloženi metod pogledaju vrednosti pragova u tabeli 4 , može se primetiti da su vrednosti praga veće na televizijskoj slici bliske i termovizijskoj slici daleke scene. Kako je vrednost verovatnoće lažnog alarma ista za sve slike može se zaključiti da je fluktuacija nivoa sivog izraženija na televizijskim slikama bliske i na termovizijskim slikama daleke scene. U slučaju četiri metoda iz literature primećuje se da su vrednosti pragova za termovizijske i televizijske slike bliske scene jako blizu.

\section{Zaključak}

U radu je izvršeno poređenje pet metoda za određivanje praga detekcije pokreta na slici scene. Metodi su testirani na sintetičkim i realnim slikama, a rezultati detekcije pokreta izraženi su kvantitativno ili su dati vizuelno. Kvantitativna analiza izvršena je na nivou piksela, a zasnovana je na procentu ispravno klasifikovanih piksela, Jaccardovom i Yuleovom koeficijentu. Za potrebe testiranja na slikama realne scene izvršeno je nekoliko snimanja. Slike scene snimljene su nepokretnom televizijskom i termovizijskom kamerom.

Kroz analizu sprovedenu u četiri eksperimenta može se izvesti zaključak da su najbolji rezultati detekcije, kvalitativno i kvantitativno, postignuti ukoliko se koristi Kapurov metod određivanja praga. Nešto lošiji rezultati dobijaju se ukoliko se koristi Rosinov metod. Ukoliko se koriste Otsuov i Tsaijev metod određivanja praga detekcije pokreta dobijaju se znatno lošiji rezultati. Rezultati koji se dobijaju po ova dva metoda zavise od broja pokretnih piksela. Ukoliko je mali broj pokretnih piksela ili pokret ne postoji, ova dva metoda daju veliki broj lažnih alarma. Rezultati se znatno poboljšavaju ukoliko raste broj pokretnih piksela.

Rezultati koji su dobijeni u slučaju korišćenja metoda autora bolji su od Otsuovog i Tsaijevog, a nešto lošiji od Kapurovog i Rosinovog metoda. Polazeći od načina na koji se došlo do vrednosti praga po ovom metodu, može se očekivati da predloženi metod daje bolje rezultate klasifikacije ukoliko na sceni ne postoji pokret. To je u analizama i potvrđeno. U slučaju da na sceni postoji pokret, rezultati zavise od toga koliko dobro je procenjena 
standardna devijacija šuma slike razlike i kolika verovatnoća lažnog alarma želi da se postigne. Vrednost praga po ovom metodu ne zavisi od broja pokretnih piksela $\mathrm{i}$ od nivoa sivog pokretnih objekata.

Literatura:

[1] Otsu, N.: A Threshold Selection Method from Gray-Level Histograms, IEEE Trans. on Systems, Man, and Cybernetics, Vol. SMC-9, No. 1, January 1979.

[2] Tsai, W. H.: Moment-Preserving Thresholding: A New Approach, Computer Vision, Graphics, and Image Processing 29, pp. 377-393, 1985.

[3] Kapur, J. N.; Sahoo, P. K.; Wong, A. K. C.: A New Method for Gray-Level Picture Thresholding Using the Entropy of the Histogram, Computer Vision, Graphics, and Image Processing 29, pp. 273-285, 1985.

[4] Rosin, P. L.; Ellis, T.: Image difference threshold strategies and shadow removal, In British Machine Vision Conf. pp. 347-356, 1995.

[5] Bondžulić, B.: Detekcija pokreta na slici scene, Magistarski rad, Elektrotehnički fakultet, Beograd, 2005.

[6] Popović, M.: Digitalna obrada slike, Rukopis za pripremanje ispita, Beograd, 1998.

[7] Cavallaro, A.; Gelasca, E. D.; Ebrahimi, T.: Objective evaluation of segmentation quality using spatio-temporal context, Proc. of IEEE International Conference on Image Processing, Rochester (New York), 22-25 September 2002.

[8] Black, J.; Ellis, T.; Rosin, P.: A Novel Method for Video Tracking Performance Evaluation, Joint IEEE Int. Workshop on Visual Surveillance and Performance Evaluation of Tracking and Surveillance (VS-PETS), 2003.

[9] Rosin, P. L.; Ioannidis, E.: Evaluation of global image thresholding for change detection, Pattern Recognition Letters 24, pp. 2345-2356, 2003. 